\title{
la socialisation des plantes chez les Baruya (Papouasie-Nouvelle-Guinée)
}

Jean-Luc Lory

\section{(2) OpenEdition \\ Journals}

Édition électronique

URL : https://journals.openedition.org/tc/953

DOI : $10.4000 /$ tc.953

ISSN : 1952-420X

Éditeur

Éditions de l'EHESS

\section{Édition imprimée}

Date de publication : 1 juin 1985

ISSN : 0248-6016

\section{Référence électronique}

Jean-Luc Lory, «la socialisation des plantes chez les Baruya (Papouasie-Nouvelle-Guinée) »,

Techniques \& Culture [En ligne], 5 | 1985, mis en ligne le 25 janvier 2006, consulté le 29 septembre 2022. URL : http://journals.openedition.org/tc/953 ; DOI : https://doi.org/10.4000/tc.953

Ce document a été généré automatiquement le 29 septembre 2022.

Tous droits réservés 


\section{la socialisation des plantes chez les Baruya (Papouasie-Nouvelle-Guinée)}

Jean-Luc Lory 